\title{
Greening Warsaw's transport system by sustainable urban planning
}

\author{
J. Malasek \\ Road and Bridge Research Institute, Warsaw, Poland
}

\begin{abstract}
Coordination of spatial and transport planning policy for modern land management in Warsaw follows the guidelines prepared in three main city documents: "Development strategy for the city of Warsaw until 2020", "The study of Warsaw spatial development conditions and directions of development" and "The strategy for sustainable development of Warsaw transport system by 2015 and subsequent years". It helps to make public transport modes more attractive for passengers and to achieve the wide public acceptance for car traffic restrictions. Sustainable urban planning is a chance for improvement, or at least not worsening, living standards in metropolis, where streets over packed by cars make cities less attractive not only for inhabitants, but also for visitors and investors.

The most important achievement of Polish urban planning practice is that all documents shaping conditions for Warsaw's sustainable development are well correlated. The development strategy formed the general guidelines which were implemented in Warsaw's spatial policy. Transportation policy, the city document prepared as the last one, forms main objectives following the spatial policy guidelines. This Warsaw experience could be followed by other Central European cities implementing modern land management for urban dynamics. Warsaw, the capital city of Poland, shares its experience in sustainable urban planning, taking part in the European project GUTS (Green Urban Transport Systems) for improvement in quality of life factors.
\end{abstract}

Keywords: urban planning, transportation policy, sustainability. 


\section{Introduction}

Coordination of the spatial and transport planning policy looks to be the best tool for sustainable city growth management. It helps in organizing multifunctional and intensive land use which forms a good basis for the development of environmental friendly concerns and is more attractive for people's public transport rail modes. In a compact city travel distances are shorter, what prefers cycling and walking instead of car using. This paper presents the guidelines for "green" urban planning using Warsaw's example.

Warsaw, the capital of Poland and the biggest city with a population over 1.7 million, has just finished the set of documents for effective city management. Coordination of the spatial and transport planning policy follows the guidelines prepared in three main city documents:

- "Development strategy for the city of Warsaw until 2020",

- "The study of Warsaw's spatial development conditions and directions of development",

- "The strategy for the sustainable development of Warsaw's transport system by 2015 and subsequent years".

All documents listed above are concentrated on the issue of the city's sustainable development.

Apart from the coordination of spatial and transport planning polices, Warsaw fights for sustainability changing its public transport fleet to be more environmentally friendly and improving traffic conditions for cyclists and pedestrians. All these measures are developed within the EU project GUTS Green Urban Transport Systems [1].

\section{Development strategy for the city}

The work on the development strategy for Warsaw [2] proceeded in various directions. Two documents were drawn up: The report on the state of the city, i.e. a diagnosis, and the Development strategy. The plans were consulted with citizens. The work was carried out by employees of Warsaw City Hall, as well as external consultants and experts, mainly the scientists from universities and research institutes. The work on the strategy was conducted by seven sub-teams on: city policy, land development, public safety, transport and traffic engineering, technical infrastructure, social infrastructure and environmental protection. The most important findings of the SWOT analysis are listed below.

On the basis of analysis five strategic objectives were formulated:

1. To improve the quality of life and safety of the residents of Warsaw

2. To consolidate the residents' sense of identity by fostering tradition, developing culture and stimulating social activity

3. To develop metropolitan functions, strengthening Warsaw's position on a regional, national and European level

4. To develop a modern economy, based on knowledge and scientific research

5. To achieve sustainable spatial order in Warsaw. 
Table 1: $\quad$ SWOT analysis for Warsaw development strategy.

\begin{tabular}{|c|c|}
\hline 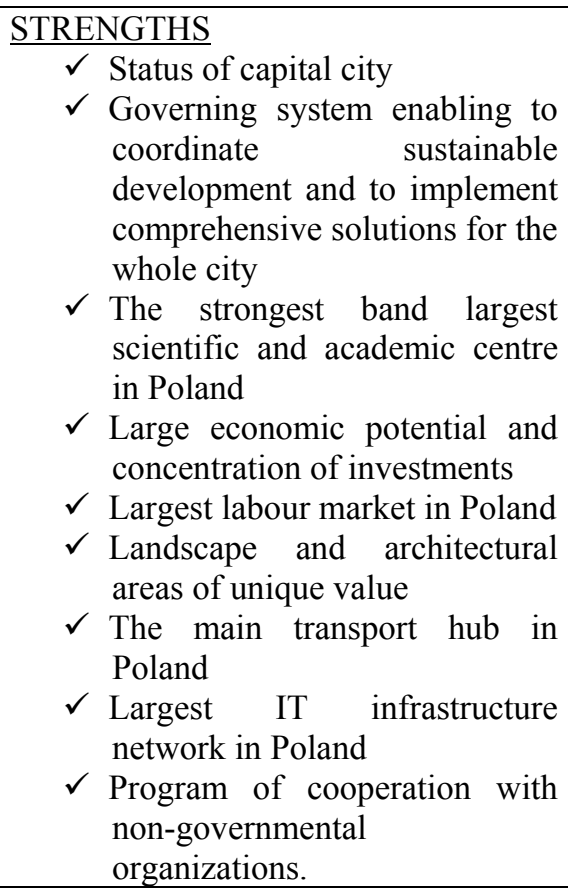 & $\begin{aligned} \text { WEAKNESSES } \\
\checkmark \text { Lack of inhabitants } \\
\text { identification with the city } \\
\text { and lack of the city } \\
\text { trademark } \\
\checkmark \text { Weak connections between } \\
\text { science and business } \\
\checkmark \text { Lack of big enough trade } \\
\text { and exhibition centers } \\
\checkmark \text { Lack of clearly defined city } \\
\text { centre and district centers } \\
\checkmark \text { Unclear state of land } \\
\text { ownership low } \\
\checkmark \text { Small number and low } \\
\text { quality of local land } \\
\text { development plans } \\
\checkmark \text { Lack of ring roads. }\end{aligned}$ \\
\hline $\begin{array}{l}\text { OPPORTUNITIES } \\
\checkmark \checkmark \text { Change with respect to the legal } \\
\text { aspects of metropolises } \\
\text { management } \\
\checkmark \text { Potential of the city to reach } \\
2.5 \text {-3 million inhabitants } \\
\checkmark \text { The largest science and } \\
\text { technology centre in Poland } \\
\checkmark \text { Inflow of foreign investments } \\
\checkmark \text { Availability of the European } \\
\checkmark \text { Union structural funds } \\
\checkmark \text { Urban revitalization programs } \\
\checkmark \text { Keeping a high number of } \\
\checkmark \text { public transport users } \\
\checkmark \text { Development of cultural } \\
\text { tourism }\end{array}$ & $\begin{aligned} \text { THREATS } \\
\checkmark \text { Poor cooperation between } \\
\text { local governments within } \\
\text { the Warsaw metropolis } \\
\checkmark \text { Migration of companies and } \\
\text { wealthier inhabitants to } \\
\text { suburban areas } \\
\checkmark \text { Low level of investment in } \\
\text { research and development } \\
\text { by the private sector } \\
\checkmark \text { Spatial dispersed } \\
\text { through } \\
\text { development } \\
\checkmark \text { Lack of the modernization } \\
\text { program for housing estates } \\
\checkmark \text { Lack of an institution } \\
\text { coordinating public } \\
\text { transport at metropolitan } \\
\text { level tourist } \\
\checkmark \text { Small number of tons } \\
\text { class hotels. }\end{aligned}$ \\
\hline
\end{tabular}


One of the strategic objectives of city development is the introduction of spatial order. Realizing this target makes it necessary for the local government authorities to manage spatial policy in line with the city's needs and development potential. Spatial policy, as conducted by the authorities of Warsaw, concentrates on satisfying needs and raising the living standard in the city. The primary aim of these actions is a striving for Warsaw inhabitants to achieve satisfaction derived from good living conditions in the metropolis with broadly developed cultural, educational and sport-recreational functions, as well as modern and convenient transport, social and service infrastructure. The capital is to become a city that is people friendly and guarantees prosperity for the whole of society.

The basic task of architectural and spatial planning design is the defining of streets and public space as common areas. Each area or district of the city should make it possible for the inhabitants to feel the character and climate of the place, while the intensity and selection of building functions should facilitate pedestrian access to adjacent public transport stations and stops, so these can become attractive alternatives to the automobile. The development of a contemporary metropolis must take into account vehicular traffic while simultaneously respecting pedestrian needs.

The city should concentrate a broad spectrum of public and private functions in order to support the regional economy and satisfy the needs of inhabitants of various income groups. Public, administrative and commercial functions should be located within housing districts so that many daily activities can take place within range of pedestrian or cycling access.

Districts should be characterized by compact, multifunctional building tissue, the interconnected street network should be designed to foster walking and cycling in order to decrease the number and length of car trips, as well as to save energy. Diverse green areas, ranging from playgrounds to playing fields and public gardens, should be provided in each city district.

\section{Spatial policy}

The spatial policy of Warsaw follows all strategic objectives formulated in development strategy and is derived from "The study of Warsaw's spatial development conditions and directions of development" [3] ratified by the Warsaw City Council in October 2006.

The study is a planning document defining spatial development for the borough, encompassing its entire area. It serves a coordination role in programming the development of the city as established in development strategy as well as in preparing multiyear investment plans and local spatial development plans, primarily in the implementation of public investment projects. It also serves as a formal document in preparing applications for approving of resources from the European funds. However the Study is not a provision of local law and therefore, cannot serve as a basis for making administrative decisions in connection with the implementation of projects in the city. 
The development of Warsaw as a European metropolis shall concentrate on guaranteeing spatial conditions for balanced and sustainable economic and social development, the protection of cultural and natural heritage and the achievement of European living standards by its inhabitants.

The spatial policy objectives are:

1. Improvement in the spatial order of the city through actions such as defining of principles for organizing and shaping elements forming the spatial structure of Warsaw.

2. Protection of existing and creation of new elements of the city sustainable development.

3. Defining principles of molding as well as the development of the system of protected areas with urban, culture and nature values.

4. Improving the efficiency and development of transport system.

5. Improving the functioning and the development of technical infrastructure.

The study defines conditions for the achieving of efficient transportation links, the creation of new, multifunctional spatial structures, the molding and protection of natural and cultural values and improving the quality of public space.

In the area of shaping the spatial structure and landscape of Warsaw, it has been established that changes shall be aimed at urban quality and the protection of the environment, while actions shall be mainly subordinated to changes in the cityscape that stress and underscore elements shaping a unique image of the city and defining the quality of municipal space.

Due to the presence of similarities in building quality and land development, the area of Warsaw has been divided into three basic functional zones:

- the downtown functional zone (including an identified city center area),

- the urban zone and

- the suburban zone,

$-$

for which development guidelines and directions of change have been formulated.

The reason behind the establishing guidelines managing changes and shaping elements of spatial structure is its protection and the stressing of existing values as well as the raising of the standard of development of elements molding that structure.

The spatial policy gives recommendations for the city elements forming the spatial structure of Warsaw.

The basic principle in Warsaw land use is balancing of functions throughout the whole area of the city and creation of multifunctional spatial structures. It is in accepting this assumption that functional zones have been isolated and consist of small areas of uniform or mutually non-colliding types of development. The following types of land use have been identified: 
- Multifunctional area concentrating services of an international, national and citywide nature;

- Service area;

- Residential area, including areas with a majority of multifamily and single-family buildings;

- Production-service land;

- Green areas of different types (forest, park, riverside, cemetery);

- Engineering infrastructure facilities;

- Transport facilities.

Warsaw environmental protection program identifies objectives, priorities and tasks whose implementation is served by legal instruments. Among these, spatial planning occupies a special place. Actions in the area of environmental protection have been founded in the directions of Warsaw's spatial policy. The main aims of the city's spatial development policy in case of protection of the environment and its resources include:

$\checkmark$ Protection of the environment, nature and landscape values;

$\checkmark$ Improvement in the quality of surface waters and protection of water resources;

$\checkmark$ Protection against noise caused by transportation and industry;

$\checkmark$ The achievement of required standards in atmospheric air quality;

$\checkmark$ Acting against threats to the environment as caused by industrial accidents as well as in the transportation of hazardous materials.

\section{Urban transportation policy}

The transportation policy is a part of "The strategy of sustainable development of Warsaw transport system by 2015 and subsequent years" [4], ratified by the City Council in April 2009. The results of analyses presented in the city transport system diagnosis [5] formed the base for the SWOT analysis, whose main findings are presented below.

In the process of creating the strategy, numerous possible variants of transport policy for the Capital City of Warsaw were considered. As a consequence, it was assumed that it is justified and necessary to assure balance between travelling by cars and public transport with consideration for the important role of pedestrian and bicycle traffic. With the deficit of transportation space, poor environment quality and limited funds, control of access to selected city areas for car traffic is necessary. Those restrictions, however, should be compensated by good public transport services, establishing the ring roads and creating favourable conditions for pedestrian and bicycle traffic.

The general goal of the transport policy of Warsaw is such an improvement and development of the transport system that would allow creating conditions for the efficient and safe movement of people and goods while limiting the harmful influence on the natural environment and living conditions. 
Table 2: $\quad$ SWOT analysis for Warsaw transport system.

\section{STRENGTHS}

1. Implemented since 1995 transport policy for Warsaw based on the principles of transport system sustainable development.

2. Well developed public transport network of high density.

3. Significant share of public transport in servicing internal journeys.

4. Implemented program of tram routes modernization and development.

5. Transparency of roads system - rectangular in the central zone and radial outside that area. During the recent years two bridges have been completed, which allowed improving the conditions of traffic across the Vistula River.

6. Wide right-of ways within the existing built-up areas, also in the city center.

7. Reserves of land for development of road infrastructure.

8. Close vicinity of the international airport.

\section{WEAKNESSES}

1. Limited extent of the transport policy implementation.

2. Low standard of collective transport services, particularly as a result of the applied vehicle filling standard ( 6 or even 8 passengers per $1 \mathrm{~m}^{2}$ of standing space), frequency and quality of rolling stock.

3. Absence of an institution managing and coordinating public transport at the level of agglomeration.

4. Absence of efficient interchanges for various means of transport.

5. Insufficient preferences in traffic for public transport in central area of the city and in the main access corridors.

6. Insufficient development of bicycle routes network infrastructure, particularly in central area and on access to public transport hubs.

7. Poor road infrastructure maintenance causing alarming status of some roads and viaducts.

8. Insufficient number of bridges across Vistula.

9. Low level of traffic safety.

10. Poorly developed Park and Ride system.

11. Poor parking regulations. 
Table 2: $\quad$ Continued.

\section{OPPORTUNITIES}

1. Opportunity for coordinated implementation of spatial and transport polices.

2. Possibility of co-funding of transport projects from the EU funds.

3. High number of public transport users.

4. Reserves of capacity and speed in tramway transport system.

5. Public consent for public transport priority in traffic.

6. Continuous interest of the public in improvement and development of transport system.

7. Improvements in traffic organization and implementation of effective traffic management systems using modern technologies.

8. Increasing potential of private carriers in public transport.

9. Increasing interest of city residents in using bicycles, including commuting to school and work.

\section{THREATS}

1. Gaps in law limiting the possibilities of efficient public transport management in the scale of the agglomeration.

2. Prolongation of the investment process resulting with lengthy legal procedures of obtaining administrative decisions.

3. Increasing costs of transport infrastructure construction.

4. Spatial disintegration of the city and agglomeration what increase demand for transport services.

5. Public expectations that the solution of transport difficulties can be achieved mainly by street network development.

6. Frequent changes in long-term plans of modernization and development of the transport system.

7. Absence of approved local plans clearly determining the concepts of physical and transport system development.

8. Taking decisions concerning investment priorities without comprehensive comparative socioeconomic analysis.

In reference to the general goal of transport policy, main objectives were formulated:

1. Assuring better accessibility in internal and external connections, by development of road connections between city districts as well as links in metropolitan, regional, national and international scale,_integration of public transport system within the entire Warsaw agglomeration and improvement of transport management.

2. Improvement of travel standards including improved access to the transport system for the disabled, by upgrading of travel standards in 
public transport and improvement of travel conditions for people with limited mobility.

3. Stimulating of economic development and spatial order, by rationalization of travel behavior of residents, restoring the urban functions of streets, increasing transport system performance effectiveness and rationalization of physical development of the city.

4. Improvement of traffic and personal safety of transport system users, by the road safety and personal safety of all transport system users improvement.

5. Improvement of the natural environment status and decreasing transport arduousness for residents, by_limiting noise emissions_and protection of air and water quality.

6. Increasing the prestige and improving the city image, by the landscape and urban space quality improvement, increasing the attractiveness of the city to investors and bringing the city closer to the Vistula River.

\section{Measures for spatial and transportation polices coordination}

The most important is that all documents shaping conditions for Warsaw's sustainable development are well correlated. The development strategy formed the general guidelines which were implemented in Warsaw's spatial policy. The transportation policy, the city document prepared as the last one, forms its main objectives following the spatial policy guidelines. The most important from a spatial planning point of view, the specific objectives of the transport policy are:

* Improvement of access to main travel destinations using other modes of transport than cars;

* Rationalization of travel behaviour of residents;

* Restoring the urban functions of streets;

* Rationalization of physical development of the city;

- Mitigating inequalities of public transport services between individual areas of the city;

Landscape quality improvement;

Urban space quality improvement.

The specified measures for implementation of the transport policy will be applied to a diversified extent depending on the character of the area. In strongly urbanized areas of the city characterized by a concentration of travel destinations, priority for public transport is increased. Another approach to transport organization is applied in areas of more scattered development. The 
role of public transport in such areas is smaller, with the exception of the radial directions leading to the city center. In those areas good cooperation and coordination of various means of public transport, e.g. transport of passengers by buses to tramway stops and underground stations are necessary. There is also a possibility of better satisfaction of expectations of motorists as concerns the possibilities of unrestricted use of private cars.

Practical implementation of the above principles will involve dividing the city into three zones differing in:

- access restrictions for cars and heavy vehicles;

- requirements concerning the public spaces and conditions for pedestrian and bicycle traffic;

- level of privileges for public transport;

- requirements concerning the number of parking spaces;

- level of parking fees diversified also on the basis of parking time.

IN ZONE I - city center, including:

- sub-zone Ia - covering the city core on the left and right banks of Vistula river with the areas of existing intensive development,

- sub-zone $\mathrm{Ib}$-covering the area allocated for transformation and intensification of existing development,

- sub-zone Ic - covering the remaining areas of city center,

the car traffic is restricted and in some areas and selected routes eliminated entirely. This is accompanied by priority treatment of public transport, restriction and in some cases ban on car traffic, limitation the number of parking spaces and introduction of pedestrian areas.

IN ZONE II - urban, that encompasses the remaining areas of compact development as well as district service centers, while priority for public transport is maintained, more freedom for use of private cars is offered.

In the remaining areas with low intensity of development forming ZONE III suburbs the system of roads and supply of parking spaces are adjusted to the needs resulting from the level of motorization. In zones II and II particular attention will be paid to the quality of public transport connecting them with the center of Warsaw (zone I).

According to the accepted transport policy, in the city center public transport will fulfill the basic role in servicing the area. The possibilities of access by cars will be limited and in selected areas, in justified cases, also eliminated. In particular, the restrictive activities will apply to transit traffic.

As concerns the limits for construction of new parking places detailed parking standards will be developed, effective in individual zones of the city. The indicators presented below form the basis for determining the parking standards.

In the destination areas of bicycle travels (offices, trade and service facilities) a minimum of 5 places for bicycles should be provided per $1000 \mathrm{~m}^{2}$ of usable area. 
Table 3: $\quad$ Parking indicators.

\begin{tabular}{|c|c|c|c|}
\hline \multicolumn{4}{|c|}{ Parking indicators } \\
\hline & For offices & $\frac{\text { For trade and }}{\underline{\text { services }}}$ & For residents \\
\hline \multicolumn{4}{|l|}{ Zone I } \\
\hline $\begin{array}{c}\text { sub-zone } \\
\text { Ia }\end{array}$ & $\begin{array}{c}\text { not more than } 5 \\
\text { places } / 1000 \mathrm{~m}^{2} \text { of } \\
\text { usable area of office } \\
\text { space }\end{array}$ & $\begin{array}{l}\text { not more than } 10 \\
\text { places } / 1000 \mathrm{~m}^{2} \text { of } \\
\text { usable area of trade } \\
\text { and services space }\end{array}$ & $\begin{array}{c}1 \text { place } / 1 \text { apartment or } \\
\text { less }\end{array}$ \\
\hline $\begin{array}{c}\text { sub-zone } \\
\text { Ib }\end{array}$ & $\begin{array}{c}\text { not more than } 10 \\
\text { places } / 1000 \mathrm{~m}^{2} \text { of } \\
\text { usable area of office } \\
\text { space }\end{array}$ & $\begin{array}{l}\text { not more than } 15 \\
\text { places } / 1000 \mathrm{~m}^{2} \text { of } \\
\text { usable area of trade } \\
\text { and services space }\end{array}$ & $\begin{array}{c}1 \text { place } 1 \text { apartment or } \\
\text { less }\end{array}$ \\
\hline $\begin{array}{l}\text { sub-zone } \\
\text { Ic }\end{array}$ & $\begin{array}{c}10-18 \text { places } / 1000 \\
\mathrm{~m}^{2} \text { of usable area of } \\
\text { office space }\end{array}$ & $\begin{array}{c}15-25 \text { places } / 1000 \\
\mathrm{~m}^{2} \text { of usable area of } \\
\text { trade and services } \\
\text { space }\end{array}$ & 1 place/1 apartment \\
\hline Zone II & $\begin{array}{c}18-30 \text { places } / 1000 \\
\mathrm{~m}^{2} \text { of usable area of } \\
\text { office space }\end{array}$ & $\begin{array}{l}25-38 \text { places } / 1000 \\
\mathrm{~m}^{2} \text { of usable area of } \\
\text { trade and services } \\
\text { space }\end{array}$ & $\begin{array}{l}1 \text { place } / 1 \text { apartment } \\
\text { but not less than } 1 \\
\text { place } / 60 \mathrm{~m}^{2} \text { of } \\
\text { apartment usable area }\end{array}$ \\
\hline Zone III & $\begin{array}{c}25-30 \text { places } / 1000 \\
\mathrm{~m}^{2} \text { of usable area of } \\
\text { office space }\end{array}$ & $\begin{array}{c}30-60 \text { places } / 1000 \\
\mathrm{~m}^{2} \text { of usable area of } \\
\text { trade and services } \\
\text { space }\end{array}$ & $\begin{array}{l}\text { minimum } 1 \text { place } / 1 \\
\text { apartment but not less } \\
\text { than } 1 \text { place } / 60 \mathrm{~m}^{2} \text { of } \\
\text { apartment usable area }\end{array}$ \\
\hline
\end{tabular}

\section{Conclusions}

The most important achievement of Polish urban planning practice is that all documents shaping conditions for Warsaw's sustainable development are well correlated. The development strategy formed the general guidelines which were implemented in Warsaw's spatial policy. The transportation policy, the city document prepared as the last one, forms its main objectives following the spatial policy guidelines.

One of the strategic objectives of city development is the introduction of spatial order. Realizing this target makes it necessary for the local government authorities to manage spatial policy in line with the city's needs and development potential. Spatial policy as conducted by the authorities of Warsaw concentrates on satisfying needs and raising the living standard in the city. The 
primary aim of these actions is a striving for Warsaw inhabitants to achieve satisfaction as derived from good living conditions in the metropolis with broadly developed cultural, educational and sport-recreational functions, as well as modern and convenient transport, social and service infrastructure.

Spatial planning and transportation measures described above are implemented in all local plans which are preparing for Warsaw area. Traffic calming in central areas and within housing estates, improving public transport attractiveness and new parking standards support sustainable Warsaw development, as a city with more compact and multifunctional structure, more environmentally and people friendly. This Warsaw experience could be followed by other Central European cities implementing modern land management for urban dynamics.

\section{References}

[1] http://www.gutscentral.eu/.

[2] Strategia rozwoju m. st. Warszawy do roku 2020 (Development strategy for the city of Warsaw until 2020) - Warsaw City Hall: 2005.

[3] Studium uwarunkowań kierunków zagospodarowania przestrzennego m. st. Warszawy (The study of Warsaw spatial development conditions and directions of development) - Warsaw city Hall: 2006.

[4] Strategia zrównoważonego rozwoju systemu transportowego Warszawy do roku 2015 i na lata kolejne (The strategy for sustainable development of Warsaw transport system by 2015 and subsequent years) - Warsaw City Hall: 2009.

[5] Reksnis, M. (editor), Czyli o strategii zrównoważonego rozwoju systemu transportowego Warszawy (About the strategy for sustainable development of Warsaw transport system) - Krajobraz Warszawski No 105, Nov. 2009.
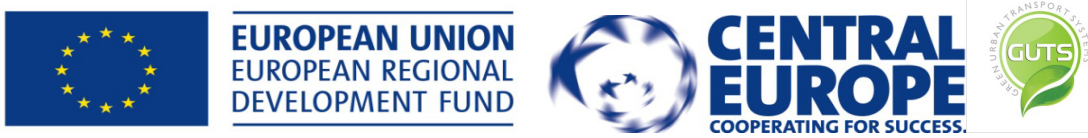